\title{
FORMALIZATION OF DO IT YOURSELF (DIY) URBANISM THROUGH CO-PRODUCTION: EXAMPLES FROM TURKEY
}

\author{
Atay Kaya İlgi* and Kut Görgün Esra \\ Dokuz Eylül University, Faculty of Architecture, Department of City and \\ Regional Planning (TURKEY) \\ * Corresponding author: ilgiatay [at] gmail.com \\ ilgiatay [at] gmail.com, esrakutt [at] gmail.com
}

\begin{abstract}
Despite the general negative perception, informality in urbanism is not always bad and does not only emerge in housing and economic activity areas. It also appears in and contributes to public spaces in DIY urbanism form. DIY urbanism includes informal, small scale, spontaneous interventions such as seats and signboards. This study aims at exploring the formalization process of DIY urbanism through coproduction and showing possible contributions to urban space and decision-making process with examples from Turkey. Web-based search, direct observation and visual recording are research methods. The findings show that DIY urbanism appears as a positive informal action while citizens solve their problems and meet their needs themselves rather than waiting for government or public institutions. Yet it is only positive and to be formalized if they consider public interest and do not hesitate others' interests. Formalization of DIY urbanism by co-production strengthens collaboration and communication in public space.
\end{abstract}

Keywords: DIY urbanism, informality, formalization, co-production, public space, Turkey

\section{INTRODUCTION}

Traditional approach identifies formal as modern and necessary and informal as backward, undesirable and to be eliminated [1]. Informality in urbanism as informal settlements, "slums" and spaces of informal economy [2] is usually perceived with its problems such as poverty, insecurity and inadequate infrastructure [3]. There are many contradictory adjectives associated to the informal services such as inefficient, creative, expensive, complicated, traditional, unsustainable and illegal [1]. There are a few attempts questioning the aesthetics and attractiveness of informality within the concept of "slum tourism" [4]. However, in a broader definition, urban informality refers to activities outside the control of the state $[4,5]$ or "freedom from the constraints of formal institutional life" [6]. These definitions comprise the activities other than housing and market. In addition, it does not only include neighbourhood scale but also involves micro levels such as public spaces and streets. This study focuses on these small-scale informalities, but not vendors or other personal gain aimed uses of urban space; rather, public interest considering interventions such as repairing roads and putting seats in bus stops. Apart from the widespread negative approaches in literature, 
this study aims at showing the contributions of these small-scale, informal interventions to urban space and decision-making process and exploring their formalization process through co-production.

These small-scale, informal interventions recently called DIY urbanism [7-14]. Except the example in Rome [15], it is not related to informal housing. DIY urbanism examples from the international literature are mostly American such as parklets in New York, San Francisco and Philadelphia [13], urban furniture in San Francisco [16], painted bicycle paths in Los Angeles [17] and guerrilla way finding signs in North Carolina $[7,8]$. However, there are also practices from other countries such as underground art gallery in Russia [18], playground in Carlsberg, Denmark [10], pop-up market in Tel Aviv, Israel [16], and cat shelters and benches in Izmir, Turkey [14]. Although there are DIY projects on private ownership such as Better Block Project in Texas, Dallas $[7,8]$ and guerrilla gardening in Los Angeles and New York [9, 17-18], this study concentrates on those in public spaces.

Co-production, on the other hand, is the provision of public services in which both professionals and service users or members of the community contribute substantially through regular and long-term relationships [19-20]. In an approach focusing on its differences from the collaboration in planning, it refers to statesociety engagement processes around urban development issues and it is a way of improving environments by poor urban communities, especially in the global South, when governments are unwilling or unable to serve [21]. It has different elements including co-planning, co-design, co-prioritisation, co-financing, co-management, co-delivery and co-assessment [20]. It is an arrangement and a process that requires 'conjoint responsibility' in producing public services [22]. A wide range of actors take place in co-production as co-producers including government agencies, non-profit organizations, families, neighbourhoods, communities, businesses, think-tanks, experts and individual citizens [23]. Types of co-production are user co-production and networked or community co-production which includes both users and non-users of the public services [24]. In another typology, co-production includes individual, group and collective levels, and commissioning, design, delivery and assessment phases [25]. There is a classification of co-production through the relationships between professionals and user or communities: (i) traditional provision of services delivered by professionals and consulted by userscommunities, (ii) user co-delivery of professionally designed services, (iii) full userprofessional co-production, in which they share the task of planning, designing and delivering the service, (iv) user-community co-delivery of services with professionals without formal planning or design processes, (v) user community sole delivery of professionally planned services, (vi) user/ community sole delivery of co-planned or co-designed services, (vii) traditional self-organized community provision where professionals have no direct involvement in services [19]. This last type is similar with the DIY interventions in a point of view. Another similar classification includes four types: citizens as co-commissioners, co-deliverers, coassessors and citizens having mixed roles [23].

There are both spatial and non-spatial examples of co-production. Non-spatial examples include community policing, charter schools [22], a doctor and a patient working together to improve the health of the individual, school officials and teachers work with a group of parents who have children with special needs to improve their education service qualities [25], residents organizing watch groups to 
enhance the effectiveness of public police protection, residents using fire-resistant buildings or updating their wiring systems to enhance the effectiveness of fire protection, and parental involvement in charter schools [26], an informal household waste picker cooperative collecting solid wastes in an informal settlement [27], and local associations organizing special events such as music and cultural trips, participatory budgeting in which community members influence the annual budget of a public service [19]. Spatial co-production examples include a local parks department working with citizens to design, deliver and assess the recreational services [25], community-based housing associations and public agencies working together in planning and managing social housing in deprived areas [19], and users, providers, policy-makers, and government authorities interacting for water service co-production [1].

The paper aims at exploring the possibility of processes experiencing mutual learning and establishment of relationships by the co-produced knowledge bringing the expected value or benefit to society, policy and practice. The research methodology is designed to understand the formalization processes on Turkish examples. It includes a literature survey, a web-based search of DIY urbanism and co-production examples, direct observation and visual recording. The keywords used in the web-based search include Turkish versions of "do it yourself urbanism", "tactical urbanism", "citizens did themselves", "they designed their own street/ park/ public space", "co-producing public space" and so on. Non-spatial coproduction examples found in the keyword-based web search are excluded. For example, co-producing education budget for the children of a martyr is excluded. Only examples including co-producing public spaces and services are included. Researchers also collect data from their everyday life and own experiences.

The classification of DIY urbanism examples due to their aims showed that they are realized with aims of meeting a need, creating an aesthetic value, reacting to an urban or social issue, and getting commercial gain [14]. The actors in DIY examples of Turkish cases include citizens, NGOs, private companies, public institutions and collaboration of two or more groups [14]. This study concentrates on the examples that are first realized by citizens, then formalized by public institutions, and finally co-produced by various actors. Totally 67 examples are examined in this study.

\section{FORMALIZATION PROCESS OF DIY URBANISM THROUGH CO-PRODUCTION AND ITS CONTRIBUTIONS}

DIY urbanism usually emerges informally rather than waiting for the formal process (Figure 1). When there is a need or a demand in the urban public space, citizens mostly apply to the public institutions. Alternatively, they sometimes move beyond the formal process and act themselves. They find quick solutions to their problems until they are solved formally. Public institutions respond to these actions in three different ways: (i) They integrate the informal actions or designs into the formal plans or projects; (ii) They do nothing and ignore the DIY interventions; (iii) They demolish these projects and implement a different project. 


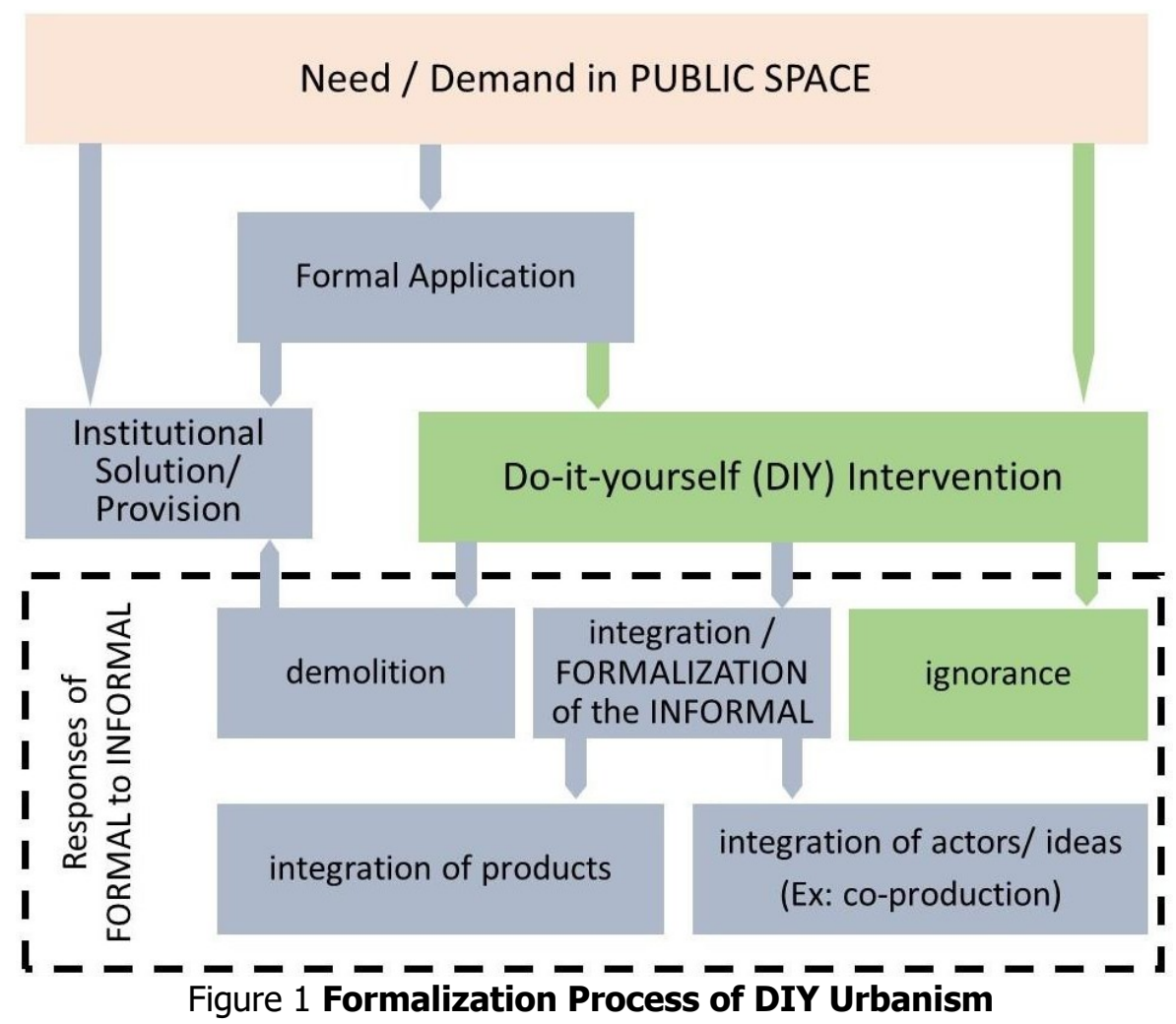

Source: The Authors.

The integration of DIY urbanism into the formal process is performed by two ways: (a) public institutions integrate the products; (b) they integrate the actors or the ideas. The actor integration is possible through various forms of participatory approaches. Co-production is one of them.

DIY urbanism, especially when it is formalized through co-production, has contributions to both urban space and urban decision-making process. First, it contributes to the public spaces by creating liveable spaces [17, 28-29], improving neighbourhood development $[30,9]$, and providing aesthetical environment [13, 31]. It also increases the quality of everyday life [30]. Moreover, it creates user friendly and vital urban environments $[10,12,17,18]$.

Second, DIY urbanism has procedural contributions to decision making. It gives active roles to citizens in creating public spaces [10, 15, 18, 32]. It gives chances to marginal groups to participate [28,33]. It improves the citizens' sense of place $[30,34]$. It promotes the relationships between citizens and increases the awareness of social capital $[17,18,35]$. It facilitates finding practical and quick solutions rather than waiting for professionals [28, 32, 33]. It includes flexible $[33]$, profitable $[30,36]$ and small-scale interventions in urban public space $[7,15$, 35].

Advantages of co-production are also several. Participating citizens influence policymaking by assisting the implementation of public goods and contributing to their preservation and sustainability [22]. Co-production has both instrumental and normative values for organizations, citizens and society [25]. It provides an integrating mechanism raising the effectiveness of public policy and creating 
opportunities for sharing power [20]. Efficiency and efficacy are higher in coproduction models than the traditional administrative models [27]. Co-production practices are more successful in small scales [23].

Some DIY urbanism examples are transformed to formal processes. There are adopted DIY urbanism practices in American cities with creative place making and planning approaches in which informality influences official planning [37]. The following part summarizes the extent of Turkish cases to experience such formalization processes.

\section{EXAMPLES FROM TURKEY}

Turkey is a lower-middle income country with nearly 81 million population [38]. There are both developed metropolitan cities with modern structures and successful public administrations, as well as developing cities with infrastructure problems and deficiencies in urban management. Whether in the former or the latter of these cities, there are examples of DIY urbanism.

Formal decision-making process in Turkish urban development includes top down decisions rarely nourished from citizens. The planning legislation regulates a process in which plans are prepared by planning authorities after collecting opinions from several institutions and then showed to citizens and other actors for one month as a plan declaration process. In this one month, the people who want to oppose to the plans appear to the authorities to change the decisions. Before the plan preparation step, the citizens can hardly find chance to "be included". However, public institutions take care of the opinions of the citizens and other actors in some practices. On the other hand, citizens act themselves either informally through DIY urbanism or formally through participating in nongovernmental organizations influencing the authorities. Interestingly, there are formalized DIY urbanism examples in which citizens, public institutions and other actors co-produce public space.

DIY urbanism actors are citizens, private companies, NGOs, public institutions, some educational institutions such as university and collaboration of two or more groups in Turkey. First part of examples that are done by single group of actors include cleaning sewage hole at Gazi Ahmet Muhtar Paşa Street in Kars Province [39], repairing electrical distribution line in Giresun Yağlıdere [40], repairing road in Tekirdağ Süleymanpaşa [41], Şanlıurfa İmam Keskin Street [42] and Adana Feke [43], constructing speed bumps in Edirne Nişancıpaşa Neighborhood [44] and Antalya Muratpaşa Kızıltoprak Neighborhood [45], putting signboards in streets in Izmir Torbalı [46], bridges in Denizli Tavas Sarıabat Neighborhood [47], Trabzon Maçka [48], Artvin Yusufeli [49], Rize Piraziz [50], Rize Pazar [51], and Muğla Marmaris [52], stairs for accessibility in Ankara Çankaya Aşıkpaşa Neighborhood [53], improving the comfort in bus stops in Düzce Merkez [54], Konya Meram [55], street furniture in Izmir Bornova Inönü, Kazım Dirik, Barbaros, Kavacık (Photo topleft in Figure 2) and Uzundere neighborhoods, street art in Izmir Kemeraltı [56], wall painting in Bursa Gemlik. Secondly, examples as stairs painting in Izmir Balçova [57] (Photo top-right in Figure 2) contain collaboration between actors. Moreover, examples as children's playground in Bursa Nilüfer [58] (Photo bottomleft in Figure 2), cat shelter in Ankara, street activities in Istanbul [59], warning signboard against disabled parking occupation [60] formalized by public institutions 
with co-production. Overall, the first group of examples (\%70) are more than the second group (\%30).
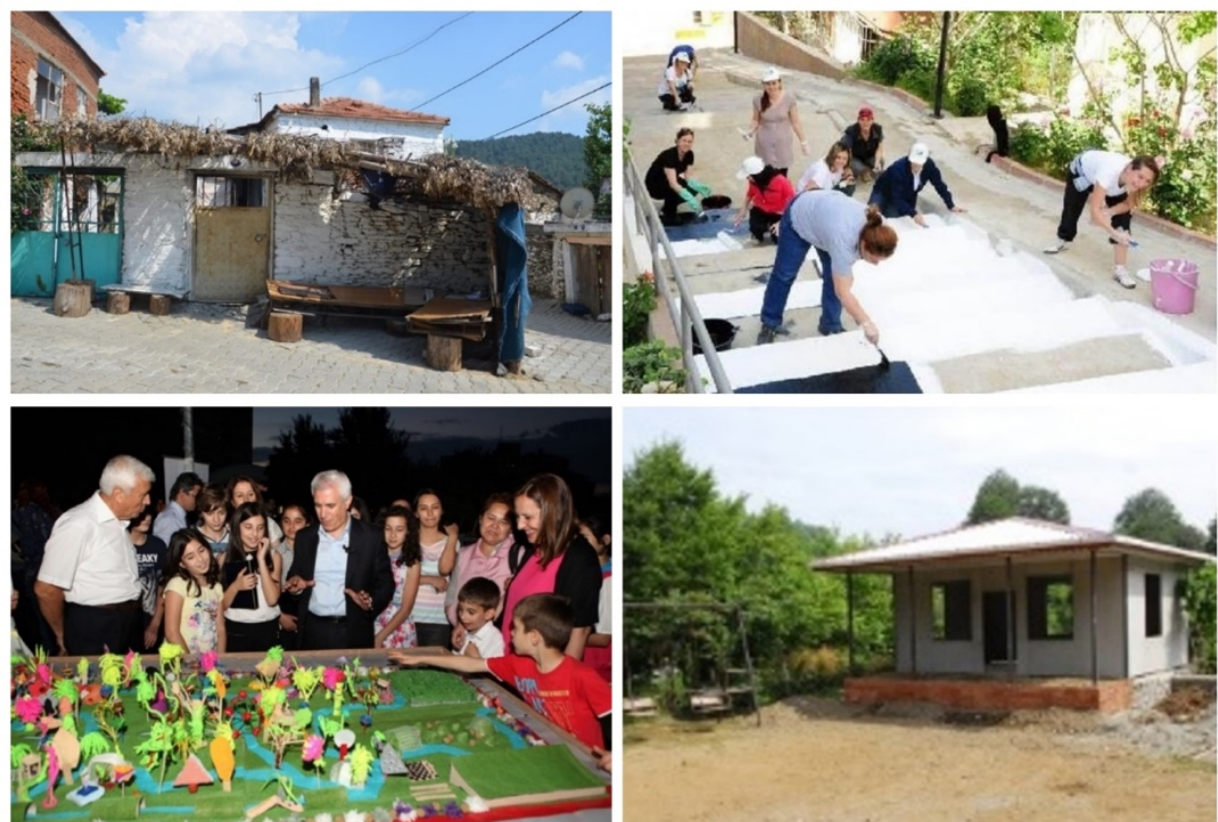

Figure 2 Photos of some DIY Urbanism and Co-production Examples in Turkey

Sources: top-left photo by 2nd Author, top-right: [56], bottom-left: [57], bottomright: [66].

On the other hand, there are two types of co-production examples in Turkey. In the first type, citizens are financial resources in public services. Building an indoor swimming pool in Kavak District of Uzunköprü in Edirne [61], a school in Çatak Village of Alaplı in Zonguldak [62] and Kuruköprü Quarter of Talas in Kayseri [63], a cold storage warehouse in Şarkıkaraağaç District of Isparta [64], and village social centers in Heydere Village of Dereli in Giresun [65], Kağılcık Village in Karamanlı District of Burdur [66] and Hopa District in Artvin [67] (Photo bottomright in Figure 2) are in this group. In the second type, citizens directly act in the production of public services. This provides benefit from the work force of the citizen rather than paying for the labor costs. Examples include installing culverts to manage rainwater in Hızarbaşı Günlük Village of Ünye in Ordu [68] and building a sewage in Çıplaklı Village of Selim in Kars [69]. As well as providing new services, citizens and/or villagers took part in repairing roads in Soğanlıyörük Village of Karadeniz Ereğlisi in Zonguldak [70] and Sarısalkım Village in Siirt [71] and restoring wooden bridge in Yukarı Boğalı Village of Tirebolu in Giresun [72]. The financial supports in these examples appearing in villages are from the local public institutions called Special Provincial Directorates. In addition, examples like building drinking water and irrigation facilities in Kavaklıdere Village of Mesudiye in Ordu [73] and repairing road in Karadikmen Village of Çamoluk in Giresun [74] are co-production practices including NGOs in addition to the public institutions and citizens.

The concepts of collaboration and direct participation are common features of 'DIY' and 'Co-production' examples. The second type of co-production examples in 


\section{\#4/2019 SUSTAINABILITY}

which citizens or villagers "do" the public services themselves are similar with the second group of DIY examples. Leading examples classified in terms of their actors in Figure 3 show that formalization increases as cooperation grows.

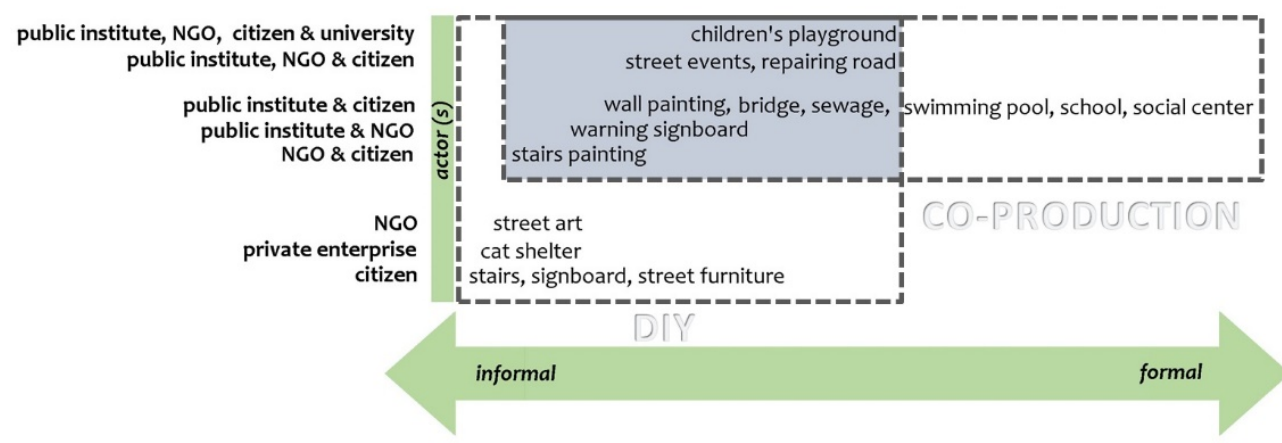

Figure 3 Leading examples of DIY Urbanism and Co-production in Turkey

Source: The Authors.

An evaluation of processes and results of DIY and co-production examples in Turkey shows that they vary in terms of (in)formality at the beginning of the process and responses of formal institution (Table 1). There are pure informal actions including DIY interventions and pure formal actions including co-production as well as the mixed processes in terms of (in)formality. These mixed processes include either unreturned formal applications before informal actions at the beginning or formalization processes after informal actions at the end.

\begin{tabular}{|l|l|l|}
\hline $\begin{array}{l}\text { Beginning of } \\
\text { the Process }\end{array}$ & $\begin{array}{l}\text { Results / Responses } \\
\text { of Formal Institution }\end{array}$ & Leading Examples \\
\hline $\begin{array}{l}\text { Informal Action } \\
\text { (DIY) }\end{array}$ & $\begin{array}{l}\text { Ignored and } \\
\text { existing }\end{array}$ & $\begin{array}{l}\text { Street furniture in Izmir Bornova Inönü, Kazım } \\
\text { Dirik, Barbaros, Kavacık and Uzundere }\end{array}$ \\
\cline { 2 - 4 } & $\begin{array}{l}\text { Integrated as } \\
\text { products } \\
\text { (Formalization) }\end{array}$ & Bridge in Rize Pazar [51] \\
\cline { 2 - 4 } & $\begin{array}{l}\text { Integrated as } \\
\text { products } \\
\text { (Formalization) }+ \\
\text { co-deciding }\end{array}$ & Bridge in Artvin Yusufeli [49] \\
\cline { 2 - 4 } & $\begin{array}{l}\text { Integrated as idea } \\
\text { (Formalization) }+ \\
\text { Demolished }+ \text { co- } \\
\text { production }\end{array}$ & Cat shelters in İzmir Buca \\
\cline { 2 - 4 } & $\begin{array}{l}\text { Demolished and not } \\
\text { existing }\end{array}$ & Bridge in Denizli Tavas Sariabat [47] \\
\cline { 2 - 4 } $\begin{array}{l}\text { No available data } \\
\text { Informal Action }\end{array}$ & $\begin{array}{l}\text { Signboards in streets in Izmir Torbalı [46], stairs in } \\
\text { Ankara Çankaya Aşıpaşa Neighborhood [53], bus } \\
\text { stops in Düzce Merkez [54] and Konya Meram [55] }\end{array}$ \\
\hline $\begin{array}{l}\text { Formal } \\
\text { explication }\end{array}$ & $\begin{array}{l}\text { Bridges in Trabzon Maçka [48] and Rize Piraziz } \\
\text { [50] }\end{array}$ \\
\hline
\end{tabular}




\begin{tabular}{|l|l|l|} 
& $\begin{array}{l}\text { Integrated as } \\
\text { services to the } \\
\text { existing formal } \\
\text { system } \\
\text { (Formalization) }\end{array}$ & $\begin{array}{l}\text { Cleaning sewage hole at Gazi Ahmet Muhtar Paşa } \\
\text { Street in Kars Province [39], repairing electrical } \\
\text { distribution line in Giresun Yağlıdere [40], road } \\
\text { repairment in Tekirdağ Süleymanpaşa [41] }\end{array}$ \\
\hline $\begin{array}{l}\text { Formal } \\
\text { Application }+ \\
\text { Informal Action } \\
\text { (DIY) }+ \\
\begin{array}{l}\text { Presented as } \\
\text { "formal" }\end{array}\end{array}$ & $\begin{array}{l}\text { Ignored and not } \\
\text { existing because of } \\
\text { natural factors }\end{array}$ & Bridge in Muğla Marmaris [52] \\
\hline $\begin{array}{l}\text { Formal (Co- } \\
\text { production) }\end{array}$ & Existing & $\begin{array}{l}\text { Children's playground in Bursa Nilüfer [58], indoor } \\
\text { swimming pool in Edirne Uzunköprü [61], schools } \\
\text { in Çatak Village of Alaplı in Zonguldak [62] and } \\
\text { Kuruköprü Quarter of Talas in Kayseri [63], and } \\
\text { village social centers in Heydere Village of Dereli in } \\
\text { Giresun [65], Kağılcık Village in Karamanlı District } \\
\text { of Burdur [66] and Hopa District in Artvin [67], } \\
\text { repairing roads in Soğanlıörük Village of } \\
\text { Karadeniz Ereğlisi in Zonguldak [70] and Sarısalkım } \\
\text { Village in Siirt [71] and restoring wooden bridge in } \\
\text { Yukarı Boğalı Village of Tirebolu in Giresun [72] }\end{array}$ \\
\cline { 2 - 4 } & Removed/ Temporal & $\begin{array}{l}\text { Street art in Izmir Kemeralti [56], street activities } \\
\text { in Istanbul [59], warning signboard against } \\
\text { disabled parking occupation [60] }\end{array}$ \\
\hline
\end{tabular}

Table 1 Processes of DIY Urbanism and Co-production in Turkey

Source: The Authors.

Plenty of examples include DIY actions without any formal applications. There is a lack of available data about the results, existing conditions and the responses of public institutions in some of these examples such as signboards in streets in Izmir Torbalı [46] (Photo top-left in Figure 4), stairs in Ankara Çankaya Aşıkpaşa Neighbourhood [53], bus stops in Düzce Merkez [54] and Konya Meram [55]. According to the available data, some pure informal DIY examples existing today face ignorance of the formal institutions. These are street furniture in Izmir Bornova Inönü, Kazım Dirik, Barbaros, Kavacık and Uzundere.

DIY attempts as products or as ideas. The formalization through integration of products is visible in the bridge example in Rize Pazar [51]. The Head of Village (Muhtar) who is the representative of the formal institutional system described it as a successful project [51].

An interesting other formalization example includes a kind of co-deciding. The process started with building an informal DIY bridge in Artvin Yusufeli [49] (Photo top-right in Figure 4), but then the villagers and the Head of Village are included in shaping the final product. A villager solved the problem of accessibility to his house in a high hill by building a suspended bridge 30 meters long and 1 meter wide. The villagers got worried about the security of their children playing on it. There was a risk that they might fall down to the stream. Then, they found a mutually accepted 
solution and co-decided to construct a door with a padlock to stop the children passing through and to prevent possible disasters.

Another novel example of formalized DIY urbanism is cat shelters in İzmir Buca (Photo bottom-right in Figure 4). At the beginning, citizens realized a need for cat shelters in a park and built a handmade space for them. For a while, public institutions ignored them. Then, both the local municipality and a public school put their own cat shelters in this park. The initial citizen-built cat shelters were first ignored, then relocated and finally demolished, but the idea was sustained. Citizens still have chance to feed the cats in the same park and manage to increase the 'formal' consciousness in terms of cat shelters.

Another DIY urbanism example, which was demolished and not existing but managed to take 'formal' attention to the problems in public services, is the bridge in Denizli [47]. In this example, there was a 'formal' bridge connecting the village to the city arterial, but it was damaged because of weather conditions and the intensity of rainfall. The villagers waited public institutions for a week and then they built a DIY wooden bridge for pedestrians.

However, the vehicle transportation was connected through the road of another village and it added two kilometres to their trip. The problem was solved, and the 'formal' bridge was repaired and the DIY one became functionless then.

Evaluation of the processes of the examples show that there are practices in which citizens first applied to the formal institutions but could not receive a solution and then they decided to 'do themselves'. Formal institutions either sustain 'doing nothing' or appreciate from these efforts. Examples of these 'ignored' and existing DIY interventions are bridges in in Trabzon Macka [48] and Rize Piraziz [50]. The former one was built 25 years ago without any permissions. The latter one is a renewed version of a series of previous bridges. In other words, in the Rize example, the citizen was building wooden bridges every year in the same location, but the weather conditions and heavy rain demolished all the previous versions. Then finally, he built a bridge made from iron and provided accessibility to his house in the hills. However, he put a locked door to the bridge to block his brother living next door to use it. He explained that the reason of this is the lack of help and financial support from his neighbouring brother. This is an example of DIY interventions damaging public interest for the sake of one's personal gain.

Processes starting with unreturned formal applications following with informal DIY actions were formalized themselves in examples of cleaning sewage hole at Gazi Ahmet Muhtar Pasa Street in Kars Province [39], repairing electrical distribution line in Giresun Yaglidere [40], repairing road in Tekirdag Süleymanpasa [41]. These are informal services integrated to the existing formal system. Each of them included a case in which there was a physical problem and damage in a formal infrastructure and a crucial and urgent action was needed but could not be provided by formal authorities on time and therefore solved by citizens either with financial or direct physical contributions in their rehabilitation or resolution.

Another rare example having a similar DIY solution with a formal application without a formal consideration is the bridge in Muğla Marmaris [52] (Photo bottom-left in Figure 4). In this example, the citizens needed a bridge on Asparan River for accessing to daily activities or services (i.e. schools). They built an informal wooden DIY bridge in 10 days with their own labour force. Interestingly, 
they presented it as 'formal' by organizing an "opening ceremony" in which they gave a name to the bridge meaning "10 Houses Bridge", put a signboard in its entrance and cut a ribbon to celebrate its construction (cutting a ribbon is a tradition in formal opening ceremonies in Turkey). Their aim was to protest the lack of attention of the formal authorities and to point out their need of an enduring bridge. However, the results of this attempt were also negative. After a while of ignorance, the bridge was demolished because of bad weather conditions.
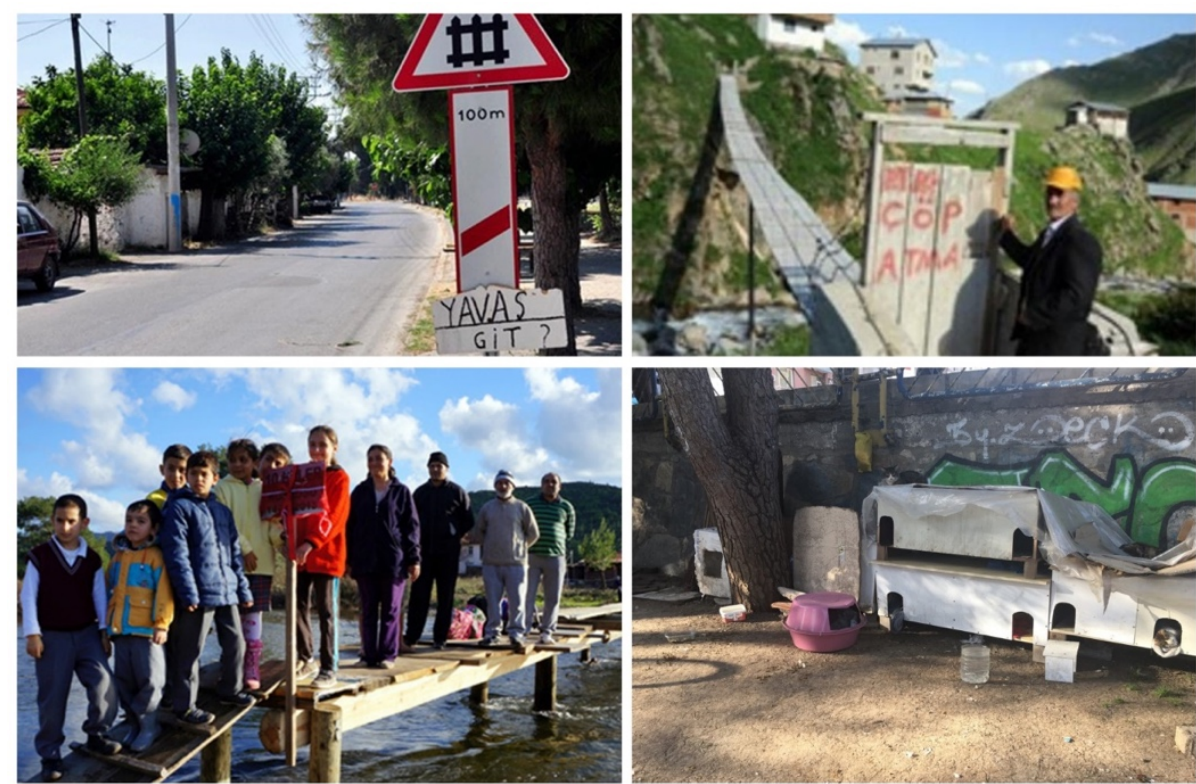

Figure 4 Photos of some other DIY Urbanism and Co-production Examples in Turkey

Sources: top-left photo: [46], top-right: [49], bottom-left: [52], bottom-right by 2nd Author.

Other examples found in the web-based search had processes started formally and appreciated co-production. While some examples such as street art in Izmir Kemeralti [56], street activities in Istanbul [59], warning signboard against disabled parking occupation [60] were either temporal or removed, the other coproduction examples such as children's playground in Bursa Nilüfer [58], indoor swimming pool in Edirne Uzunköprü [61], schools in Çatak Village of Alaplı in Zonguldak [62] and Kuruköprü Quarter of Talas in Kayseri [63], and village social centers in Heydere Village of Dereli in Giresun [65], Kağılcık Village in Karamanlı District of Burdur [66] and Hopa District in Artvin [67], repairing roads in Soğanlıyörük Village of Karadeniz Ereğlisi in Zonguldak [70] and Sarısalkım Village in Siirt [71] and restoring wooden bridge in Yukarı Boğalı Village of Tirebolu in Giresun [72] are sustaining their existence.

Overall, the evaluation of the processes of Turkish DIY urbanism and co-production examples shows that the responses from formal institutions change through the context. It is difficult to draw certain lines between formal and informal processes. It is better to focus on their aims. The projects with aims of improving spatial and physical conditions or repairing an existing public service or infrastructure are more likely to become formalized or contributed to formal systems. However, indeed, this cannot be generalized. The public interest regarding but not formalized 
examples of bridge in Marmaris [52] or street furniture in İzmir are evidences. Besides, a door located in a DIY bridge might be regarded as both positive and negative interventions. In one case, it is a sign of security and co-decided by a group of actors whereas in another case, it is a sign of barrier damaging public interest in terms of accessibility. The public interest consideration can be seen as a factor increasing positive responses of public institutions.

\section{CONCLUSIONS}

Not all informal processes are related with housing and economy, but there are also public interest based small-scale interventions in public spaces. These DIY urbanism efforts contributes to both substantial and procedural developments in cities as seen in Turkish examples. All these selected examples considering public interest tries to find solutions to urban problems and improves public spaces. None of them includes commercial or personal aims. This study used the examples to show the possible positive aspects of informal processes such as flexible, quick and issue focusing attempts rather than waiting for formal procedures. The critical point in these processes is the need for a consideration of their disadvantages. They can cause problems of conflicting with formal plans and procedures, incompatibility with legislations and lack of desire to adopt these projects, lack of financial support to implement them and the risk of manipulating them in order to get personal gain and hesitate others' interests. Planners and decision makers should be aware of these disadvantages while getting use of and formalizing DIY urbanism practices.

One of the main findings of this study is that there is a consistency of the two concepts of "co-production" and "do-it-yourself" in terms of Turkish examples. As expected, the former includes formal examples whereas the latter includes informal interventions. They are reflected to media with similar highlights and they are used as synonyms in newspaper news.

This article does not argue that every informality should be formalized; it only argues that the formalization of some informal DIY interventions is possible through co-production. The main concluding remark of this study is that coproduction of public spaces creates opportunities for both public institutions and citizens. Public institutions gain trust and supply public acceptance in their projects. On the other hand, citizens gain a chance to have a say in decision-making processes of their own living environments. Co-production in the form of formalization of public interest-based DIY urbanism projects is better than both the top down approaches missing the exact needs and/ or interests of the citizens and the informal and/ or activist actions of citizens. It provides a process involving learning by doing in which citizens and/or users of the public spaces/ services act and/ or do themselves rather than only criticizing the "already done" or "not done".

Deficiencies in data collection is a limitation of this study. The nature of the 'informality' concept limits the documentation, as the informal data could not be reached from formal institutional archives. The direct observation is not easy in the whole country with such a big geography; therefore, it could be achieved partly in this study. In addition, web-based search only shows the most interesting examples that are worth recording as news in media. A complementary further 
research will compare the DIY urbanism examples in different cities or countries by a collection of directly observed data. 


\section{REFERENCES}

[1] Ahlers, R.; Cleaver, F.; Rusca, M.; Schwartz, K. (2014), "Informal space in the urban waterscape: Disaggregation and co- production of water services", Water Altern., 7 (1), 114.

[2] King, R.; Dovey, K. (2013), "Interstitial metamorphoses: Informal urbanism and the tourist gaze", Environ. Plan. D Soc. Sp., 31, 1022-1040. https://doi.org/10.1068/d1412.

[3] Amoako, C.; Frimpong, E. (2017), "Build as You Earn and Learn: Informal Urbanism and Incremental Housing Financing in Kumasi, Ghana", J. Hous. Built Environ., 32 (3), 429 448. https://doi.org/10.1007/s10901-016-9519-0.

[4] Dovey, K.; King, R. (2017), "Informal Urbanism and the Taste for Slums", Tour. Geogr. An Int. J. Tour. Space, Place Environ., 6688 (December).

[5] Kamalipour, H. (2016), "Forms of Informality and Adaptations in Informal Settlements", Int. J. Archit. Res., 10 (3), 60-76.

[6] Laguerre, M. S. (2016), The informal city. Palgrave Macmillan; Palgrave Macmillan: UK.

[7] Benner, S. M. (2013), Tactical Urbanism: From Civil Disobedience to Civic Improvement; The University of Texas: Auistin.

[8] Pfeifer, L. (2013), The planner's guide to tactical urbanism. https://reginaurban ecology.files.wordpress.com/2013/10/tuguide1.pdf.

[9] Douglas, G. C. C. (2014), "Do-it-yourself urban design: The social practice of informal "improvement" through unauthorized alteration", City Community, 13 (1), 5-25. http://doi.org/10.1111/cico.12029.

[10] Fabian, L.; Samson, K. (2015), "Claiming participation - a comparative analysis of DIY urbanism in Denmark", J. Urban. Int. Res. Placemaking Urban Sustain., 9(2), 166-184. http:// doi.org/10.1080/17549175. 2015.1056207.

[11] Lydon, M.; Garcia, T. (2015), "Chapter 1: Disturbing the order of things. In Tactical urbanism: short-term action for long-term change", Lydon, M. Garcia, T., Eds.; Island Press, Washington, DC, 1-23. https://issuu.com/islandpress/ docs/lydon_cnu.

[12] Sawhney, N.; Klerk, C. D. E.; Malhotra, S. (2015), "Civic Engagement through DIY Urbanism and Collective Networked Action", Plan. Pract. Res., 30 (3), 337-354.

[13] Talen, E. (2015), "Do-it-Yourself Urbanism: A History", J. Plan. Hist., 14 (2), 135-148. http://doi.org/10.1177/1538513214549325.

[14] Atay Kaya, İ.; Kut Görgün, E. (2017), "Do it yourself (DIY) movement in urban space production", Plan. J, 27 (1), 57- 74.

[15] Bermann, K.; Marinaro, I. C. (2018), "'We Work It out': Roma Settlements in Rome and the Limits of Do-It-Yourself", J. Urban. Int. Res. Placemaking Urban Sustain., 9175 (January), 399-413.

[16] Mould, O. (2014), "Tactical urbanism: The new vernacular of the creative city", Geogr. Compass, 8 (8), 529-539.

[17] Finn, D. (2014), "DIY urbanism: implications for cities", J. Urban. Int. Res. Placemaking Urban Sustain., 7 (4), 381-398. http://dx.doi.org/10.1080/17549175.2014.891149

[18] Shepard, B. (2014), "DIY urbanism as an environmental justice strategy: The case study of Time's Up! 1987-2012", Theory Action, (7) 2, 42-73. http://doi.org/10.3798/tia.1937-0237.14010

[19] Bovaird, T. (2007), "Beyond engagement and participation: user and community coproduction of public services", Public Adm. Rev., 67 (5), 846-860. https://doi.org/10.1111/j.1540-6210.2007.00773.x 
[20] Bovaird, T.; Loeffler, E. (2012), "From engagement to co-production: The contribution of users and communities to outcomes and public value", Int. J. Volunt. Nonprofit Organ., 23 (4), 1119-1138.

[21] Watson, V. (2013), "Planning and the "stubborn Realities" of Global South-East Cities: Some Emerging Ideas", Plan. Theory, 12 (1), 81-100.

[22] Marschall, M. J. (2009), "Citizen Participation and the Neighborhood Context: A New Look at the Coproduction of Local Public Goods", 57 (2), 231-244.

[23] Tu, X. (2015), "Empowering Citizens in Public Services: A Systematic Review of CoProduction Cases", IRSPM Conf. 2015, 1-18.

[24] Meijer, A. J. (2011), "Networked Coproduction of Public Services in Virtual Communities: From a Government-Centric to a Community Approach to Public Service Support", Public Adm. Rev., 71 (4), 598-607. https://doi.org/DOI 10.1111/j.15406210.2011.02391.x.

[25] Nabatchi, T.; Sancino, A.; Sicilia, M. (2017), "Varieties of Participation in Public Services: The Who, When, and What of Coproduction", Public Adm. Rev., 77 (5), 766-776. https://doi.org/10.1111/puar.12765.

[26] Bifulco, R.; Ladd, H. F. (2006), "Institutional Change and Coproduction of Public Services: The Effect of Charter Schools on Parental Involvement", J. Public Adm. Res. Theory, 16 (4), 553-576. https://doi.org/10.1093/jopart/muj001.

[27] Zapata Campos, M. J.; Zapata, P. (2013), "Switching Managua on! Connecting Informal Settlements to the Formal City through Household Waste Collection", Environ. Urban., 25 (1), 225-242. https://doi.org/10.1177/0956247812468404.

[28] Spataro, D. (2015), "Against a de-politicized DIY urbanism: Food Not Bombs and the struggle over public space", J. Urban. Int. Res. Placemaking Urban Sustain., 1 (17). http://doi.org/10.1080/ 17549175.2015.1056208.

[29] Scaff, K. DIY (n.d.), Urbanism: changing communities, one piece of artwork at a time. http://www.uc.edu/cdc/images/events/diy_urbanism/DIY_Urbanism_Article.pdf.

[30] Strzelecka, M.; Sorensen, J.; Wicks, B. E. (2010), "The role of place attachment in revitalization of neighborhood parks in East St. Louis", Loisir Société/ Soc. Leis., 33 (2), 251-272. http://doi.org/10.1080/07053436.2010.10707811.

[31] Enigbokan, A. (2015), "Delai Sam: Social activism as contemporary art in the emerging discourse of DIY urbanism in Russia", J. Urban. Int. Res. Placemaking Urban Sustain., 9 (2), 101-116. http://doi.org/10.1080/17549175.2015.1029507.

[32] Campo, D. (2014), "Iconic eyesores: Exploring do-it-yourself preservation and civic improvement at abandoned train stations in Buffalo and Detroit", J. Urban. Int. Res. $\begin{array}{lllll}\text { Placemaking Urban } & \text { Sustain., } & 7 & \text { (4), } & 351-380 .\end{array}$ http://doi.org/10.1080/17549175.2014.952322.

[33] Németh, J.; Langhorst, J. (2014), "Rethinking urban transformation: Temporary uses for vacant land", Cities, 40, 143-150. http://doi.org/10.1016/j. cities.2013.04.007.

[34] Poole, S. E. (2009), "When neighborhoods need help, call in the college kids!", Park. Recreat., April, 50-55.

[35] Gamez, J. L. S.; Sorensen, J. (2014), "No more waiting for Superman: Teaching DIY urbanism and reflexive practice", J. Urban. Int. Res. Placemaking Urban Sustain., 7 (4), 333-350. http://doi.org/10.1080/17549175.2014.909516.

[36] Lydon, M.; Bartman, D.; Woudstra, R.; Khawarzad, A. (2011), Tactical Urbanism: Short term action long term change, 1, The Street Plans Collaborative. https://issuu.com/streetplanscollaborative/docs/tactical_urbanism_vol.1.

[37] Silvestre, H. C.; Catarino, J. R.; Araújo, J. F. F. E. de. (2016), "Evidence of CoProduction in Public Service Provision: The Case of the Administrative Arbitration Centre in Portugal", Rev. Adm., 51 (4), 355-365. https://doi.org/10.1016/j.rausp.2016.07.007. 


\section{\#4/2019 SUSTAINABILITY}

[38] TURKSTAT, Turkish Statistical Institute, (2018). http://www.turkstat.gov.tr. (21.06.2018).

[39] http://www.serhattv.com.tr/haber/254897/kanalizasyon-sisteminivatandas-kendiyapti.html (04.04.2016).

[40] http://www.yaglidere.com/aksanin-yapamadigini-vatandas-kendi-imkanlariyla-yapti/ (04.04.2016).

[41] http://www.59.com.tr/haber/vatandas-kendi-yolunu-kendi-yapti/1 (04.04.2016).

[42] http://www.sanliurfa.com/belediye-nin-yapmadigi-yolu-kendileriyaptilar/16714 32707/ (04.04.2016).

[43] http://www.adanayorum.com/vatandas-kendi-yolunu-kendisi-yapiyor-10491h.htm (05.04.2016).

[44] http://www.vatandasgazetesi.com.tr/gundem/vatandas-kendi-cozumunu-bulduh9531.html (04.04.2016).

[45] http://www.antalyasokaklari.com/2015/07/belediye-yapmayincamahalleli-yapti/ (06.04.2016).

[46] http://www.iha.com.tr/haber-bu-da-vatandasin-uyari-levhasi-285049/ (05.04.2016).

[47] http://www.haberdenizli.com/ilceler/vatandas-koprusunu-kendi-yapti-h14661.html (04.04.2016).

[48] http://www.netgazete.com/yasam/karadenizli-vatandas-kendibogazkoprusunu-yapti605952 (04.04.2016).

[49] http://www.hurriyet.com.tr/gundem/asma-kopruye-kilitli-kapi-takti-18124894

(20.03.2018).

[50] http://emlakkulisi.com/rizede-bir-vatandas-evine-ulasmak-icin-yaptigi-kopruye-kapitakti/237179 (04.04.2016).

[51] https://www.emlaktasondakika.com/haber/sondakikahaberleri/rizeli-recep-ali-dizginevine-ulasmak-icin-68-metrelik-kopru-yapti/75497 (20.03.2018).

[52] http://www.haber7.com/neler-oluyor-hayatta/haber/977892-tahtakopru-icin-acilistoren-yaptilar (05.04.2016).

[53] http://www.ankarasonhaber.com/vatandas-merdivenini-kendi-yapti/5383/ (.04.2016).

[54] http://beyazgazete.com/haber/2010/2/27/vatandas-yapimi-otobusduragi-47177.html (04.04.2016).

[55] http://fotogaleri.hurriyet.com.tr/galeridetay/82194/2/1/belediyeyapmayinca-vatandaskendi-duragini-yapti (04.04.2016).

[56] http://gecicimudahale.org/projeler/kemeraltina-gecici-mudahale/ atelye-calismalari/ (05.04.2016).

[57] http://www.egedesonsoz.com/haber/Merdiven-devrimi-Her-yergokkusagi/849082

(05.04.2016).

[58] http://www.nilufer.bel.tr/haber-1628-niluferde_oyun_engel_tanimaz_projesi_ tamamlandi\#prettyPhoto (04.04.2016).

[59] http://www.sokakbizim.org/ayda-bir-gun-sokak-bizim/ (06.04.2016).

[60] http://www.netgazete.com/yasam/izmir-foca-da-engelli-yolunuisgal-edenlere-carpiciuyari-683968 (05.04.2016).

[61] http://www.edirne.gov.tr/devlet-vatandas-isbirligi-ile-uzunkopruye-yuzme-havuzu (07.02.2018).

[62] https://www.haberler.com/devlet-vatandas-isbirligi-ile-yapilan-okul-insaati-8143498haberi/ (07.02.2018).

[63] http://www.kayserihakimiyet2000.com/talas-kurukopruye-devlet-vatandas-isbirligi-ileortaokul/ (07.02.2018). 
[64] http://www.gazete32.com.tr/isparta/devlet-vatandas-isbirligi-ile-yeni-bir-isletme-dahaacildi.html (07.02.2018).

[65] http://www.milliyet.com.tr/devlet-vatandas-isbirligi-ile-yapilan-giresun-yerelhaber37407/ (07.02.2018).

[66] https://www.haberler.com/devlet-vatandas-isbirligi-ile-koylere-hizmet-7863175-haberi/ (07.02.2018).

[67] http://www.kemalpasa.bel.tr/?Syf=18\&Hbr=347427\&/Devlet---vatanda\%C5\%9F¡\%C5\%9Fbirli\%C4\%9Fi-ile- yap\%C4\%B1m\%C4\%B1-devam-eden-k\%C3\%B6ykona\%C4\%9F\%C4\%B1-in\%C5\%9Faat\%C4\%B1-il\%C3\%A7e-ve-belde- k\%C3\%B6ylerindebir-ilk-olmas\%C4\%B1-Hopa-i\%C3\%A7in-ayr\%C4\%B1-bir-\%C3\%B6nemta\%C5\%9F\%C4\%B1yor (07.02.2018).

[68] http://www.mynet.com/haber/guncel/devlet-vatandas-isbirligi-ile-menfez-168664-1 (07.02.2018).

[69] http://www.gazetekars.com/devlet-vatandas-isbirligi-2952h.htm (07.02.2018).

[70] http://www.ereglionder.com.tr/guncel/devletvatandas-isbirligi-h46133.html (07.02.2018).

[71] http://www.siirtmanset.com/ilce-haber/devlet-vatandas-isbirligi-ile-koy-yolu-yapildih468.html (07.02.2018).

[72] https://www.memurlar.net/haber/400409/tahta-kopru-devlet-vatandas-isbirligi-ileonariliyor.html (07.02.2018).

[73] http://www.iha.com.tr/haber-mesudiyede-devlet-vatandas-isbirligi-285391/ (07.02.2018).

[74] http://www.camolukhaber.com/guncel/karadikmende-devlet-vatandas-isbirligi-ile-5km-yol-h1557.html (07.02.2018).

Article distributed under a Creative Commons AttributionNonCommercial-NoDerivatives 4.0 International License (CC BY-NC-ND).

Received: March 27, 2019

Accepted: April 8, 2019 